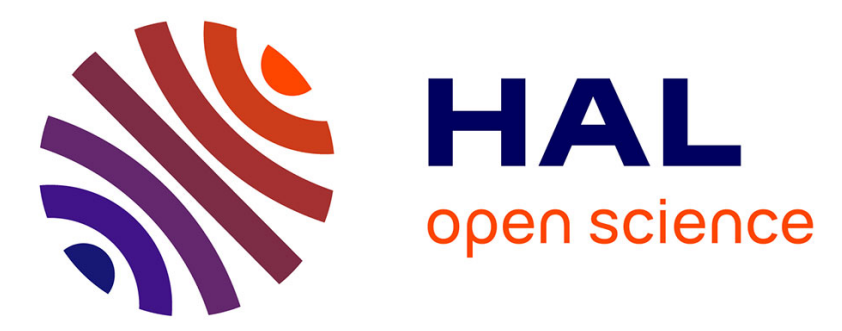

\title{
Post-rift uplift of the Dhofar margin (Gulf of Aden)
}

François Bache, Sylvie Leroy, Céline Beaurion, Jérémy Robinet, Christian

Gorini, F. Lucazeau, P. Razin, Elia d'Acremont, K. Al-Toubi

\section{To cite this version:}

François Bache, Sylvie Leroy, Céline Beaurion, Jérémy Robinet, Christian Gorini, et al.. Post-rift uplift of the Dhofar margin (Gulf of Aden). Terra Nova, 2011, 23, pp.11-18. 10.1111/j.13653121.2010.00975.x . hal-00577734

\section{HAL Id: hal-00577734 \\ https://hal.science/hal-00577734}

Submitted on 1 Dec 2011

HAL is a multi-disciplinary open access archive for the deposit and dissemination of scientific research documents, whether they are published or not. The documents may come from teaching and research institutions in France or abroad, or from public or private research centers.
L'archive ouverte pluridisciplinaire HAL, est destinée au dépôt et à la diffusion de documents scientifiques de niveau recherche, publiés ou non, émanant des établissements d'enseignement et de recherche français ou étrangers, des laboratoires publics ou privés. 


\title{
POST-RIFT UPLIFT OF THE DHOFAR MARGIN (GULF OF ADEN)
}

\author{
François Bache ${ }^{1,2 *}$, Sylvie Leroy ${ }^{1,2}$, Céline Baurion ${ }^{1,2}$, \\ Jérémy Robinet ${ }^{1,2,3}$, Christian Gorini ${ }^{1,2}$, Francis Lucazeau ${ }^{4}$, \\ Philippe Razin ${ }^{3}$, Elia d'Acremont ${ }^{1,2}$, Khalfan Al-Toubi ${ }^{5}$
}

${ }^{1}$ UPMC Univ. Paris 06, UMR 7193, ISTEP, F-75005, Paris, France

${ }^{2}$ CNRS, UMR 7193, ISTEP, F-75005, Paris, France

${ }^{3}$ Université Bordeaux 3, EGID, Pessac, France

${ }^{4}$ Geosciences Marines, IPGP-CNRS, 4 place Jussieu, 75252 Paris Cedex 05, France

${ }^{5}$ Sultan Qaboos University, Earthquake Monitoring center, Al Khod PC 123, Sultanate of Oman

\section{Abstract}

An investigation of the sedimentation pattern along the Dhofar margin allows us to describe its late-stage evolution. After the accumulation of a thick post-rift sedimentary succession, two debris flow events occurred at the foot of the slope. The first event, affecting a wide area of the margin, marks a major change in sedimentation. The second event is associated with a shift of sedimentary deposition from the slope toward the basin. This latter debris flow was caused by an uplift phase, and highlights two distinct deformational styles in the eastern and western part of the Dhofar margin. Both events occurred very late in the history of the margin, at least 7.6 Ma after the end of the rifting phase (35-17.6 Ma).

\section{Introduction}

The Gulf of Aden is a young and narrow oceanic basin formed between the rifted margins of the Arabian and African plates (Fig. 1). Kinematic studies have highlighted an oblique extension (N30 $\left.{ }^{\circ} \mathrm{E}\right)$ in relation to the orientation of the basin $\left(\mathrm{N} 75^{\circ} \mathrm{E}\right)$ (Jestin, et al., 1994, Fournier, et al., 2001). This extensional regime is associated with major transform faults (Alula-Fartak and Socotra-Hadbeen fracture zones) which delimits three major segments in the Gulf of Aden. The Dhofar margin is located in the northern part of the central segment between Longitude $53^{\circ}$ to $54^{\circ} \mathrm{E}$ and Latitude $15^{\circ}$ to $17^{\circ} \mathrm{N}$. In this part of the basin, the rifting started around $35 \mathrm{Ma}$ ago (Roger, et al., 1989, Bott, et al., 1992), followed by oceanic spreading from at least 17.6 Ma (Leroy, et al., 2004, d'Acremont, et al., 2006).

Post-rift deformation, involving tectonic reactivation, has strongly affected the structure and infilling of the extensional basins and passive margins (Cloetingh, et al., 2008). Understanding these processes is essential in identifying older episodes (syn-rift or pre-rift) of formation of the margins. This study focuses on the post-rift depositional pattern of the Dhofar margin and provides such perspectives.

One of the major contributions to this study has been the large amount of seismic data collected in onshore and offshore areas for both industrial and academic purposes (Fig. 1). Seismic interpretations have been performed using the principles of seismic stratigraphy (Vail, et al., 1977). In the present study, we identify seismic units based on stratal terminations and configurations of seismic reflections. The large coverage of seismic data enabled us to map the units throughout the Dhofar margin from the hinge line (i.e. the onset of thick sedimentary deposits toward the basin, which also corresponds to a major transition in crustal thickness) to the deep margin domain. While additional data were obtained from two industrial boreholes in the Salalah Basin (Fig. 1), only the syn-rift sediments were sampled.

\footnotetext{
* Corresponding author. Present address : iSTeP. UMR 7193 CNRS/Université Pierre et Marie Curie, 4 place Jussieu, Case
} 129, 75252 Paris cedex 05. France. E-mail address : francois.bache@upmc.fr. Tel.: +33 675045571 ; fax: +33 144275246. 


\section{Dhofar margin configuration}

The Dhofar margin (Fig. 2) has an average width of $60 \mathrm{~km}$ from the hinge line to the abyssal plain, which begins at around $2500 \mathrm{~m}$ water depth. The shelf is relatively flat, ranging between 10 and 30 $\mathrm{km}$ wide. The continental shelf break is located between 100 and $200 \mathrm{~m}$ water depth, showing indentations where the heads of submarine canyons cut into the shelf (Fig.2). The continental slope ranges in width from 20-40 km and displays a large range of mass movement features including erosional scarps, canyons and slumps (Fig. 2). Two types of canyons can be defined, according to their location on the western or eastern parts of the margin. On the western margin, the canyons are narrow, forming linear erosional troughs characterized by weak gradients $\left(\sim 1^{\circ}\right)$ along their thalweg axis. Canyons on the eastern margin have led to considerable erosion, and are characterized by steep slope $\left(\sim 3.5^{\circ}\right)$ along their thalweg axis. By contrast, the thalweg axes of channels observed on the abyssal plain show a gradient of $\sim 0.3^{\circ}$.

Under the seabed, the sedimentary cover (Figs. 3 and 4) ranges in thickness from $0 \mathrm{~s}$ TWTT on the western part of the shelf to $1.6 \mathrm{~s}$ TWTT at the foot of the continental slope in the distal margin graben (abbreviated here as DIM). The transition from the shelf to the abyssal plain exhibits two different styles. In the western part of the margin, the transition takes place across a "perched graben" containing a thickness of sediment corresponding to $1.3 \mathrm{~s}$ TWTT. This basin is bounded by two faults $\left(\sim \mathrm{N} 110^{\circ}\right)$ facing seaward, the fault located between the perched graben and the shelf showing the largest offset (Fig. 4A). In the eastern part of the margin, the transition is progressive and made up of several faults $\left(\sim \mathrm{N} 110^{\circ}\right)$ facing landward (Fig. 4C). In this domain, the sedimentary cover is thin (1 s TWTT at the very most).

\section{Early history of the Dhofar margin}

In the DIM graben, the acoustic basement is characterized by the transition between highamplitude reflections (tilted units or chaotic seismic facies) and the overlying subhorizontal sedimentary series (Figs. 4 and 5). This major unconformity, commonly known as the "break-up unconformity", has been interpreted as the abrupt transition between a tectonically active period (rifting) and a more quiescent regime (post-rift period). Recent studies have shown that this transition is complex and not limited to a single short event (Leroy, et al., 2004, d'Acremont, et al., 2005). Four seismic units can be differentiated above the acoustic basement (Autin, et al., 2010), which is overlain by the weakly deformed unit U2 representing a complex transition into the post-rift succession. Although U2 postdates the syn-rift period, it was not deposited on oceanic crust (Fig. 4). According to d'Acremont et al. (2005) and Autin et al. (2010), the U2 unit, also called the "syn-OCT" unit, is contemporaneous with the formation of the Ocean-Continent Transition (OCT). U3 is characterized by high-amplitude, parallel and highly continuous reflection configurations, and is the first unit deposited above the oceanic crust. This unit extends over a large part of the present-day continental slope domain. During U3 deposition, ocean floor accretion was active and the slope domain was submerged.

The onshore domain is mainly characterized by pre-rift and syn-rift deposits. A major change in sedimentation from a shallow environment (Ashawq Formation, Oligocene) to calcareous turbidites (Mughsayl Formation, early Miocene) has been related to the formation of grabens during the syn-rift period (Platel and Roger, 1989). These syn-rift deposits fill the Salalah Basin (Borgomano and Peters, 2004), but it is not possible to trace their geometric seaward extension due to a lack of geophysical data at the transition with offshore deposits. Post-rift sediments are poorly documented due to their poor preservation (Roger, et al., 1989). Indeed, the proximal margin was eroded, thus supplying sediment to the distal domain since the time of formation of the OCT formation (Autin, et al., 2010).

\section{Late post-rift events}

Sedimentary deposits resulting from submarine mass movements occur on all passive continental margins. Mass Transport Complexes (MTCs) include all kinds of gravity-driven or downslope deposits, with the exception of turbidites. MTCs can occur at any time during the history of a margin (Masson, et al., 1997), but commonly develop early in the cycle of relative sea-level variation during the fall toward 
lowstand, when sedimentation on the shelf edge is at its peak and water overburden weight is being reduced over the shelf domain (Posamentier and Kolla, 2003). The resulting deposits extend over the continental slope and basin floor, commonly accumulating near the foot of the slope.

On the Dhofar margin, the foot of the slope is characterized by the occurrence of low-amplitude, chaotic seismic facies (Figs. 4 and 5). Compressional features near the termination of the flow unit and the highly erosive base lead us to interpret these deposits as debris flows. The lowermost debris flows observed in U4 (Figs. 4 and 5) are surrounded by high-amplitude reflectors and leveed channels. While U5 exhibits the same characteristics, the debris flows of this unit are however mainly located in the eastern part of the margin, where they appear to occupy a greater volume (Fig. 4). MTCs (and debris flows) are generally embedded in a cyclic stratigraphic sequence composed of sandy leveed channel complexes and hemipelagic drapes (Beaubouef and Friedman, 2000). This cyclic sedimentation has been attributed to fluctuations in sea level, inducing changes in sediment supply to the shef edge (Manley and Flood, 1988, Beaubouef and Friedman, 2000, Brami, et al., 2000). However, other authors have suggested that tectonic events may be a major cause of slope destabilization (Martinez, et al., 2005, Moscardelli, et al., 2006). In the Dhofar margin, units U4 and U5 could thus represent two late-stage cycles of relative sea-level fluctuations (controlled by eustatic variations and/or tectonic movements).

Two different depositional patterns characterize the slope from West to East. On the steep eastern slope, the continuous reflections and channels of U4 (Fig. 6) are tilted or slumped toward the basin (Figs. 4B and C). U5 has not been preserved/deposited in this domain, and erosional features can be observed (Fig. 7). In the western part of the margin, units U4 and U5 are both preserved on the slope (Fig. 4A). Their seismic reflectors are poorly deformed and maintain a horizontal position. The tilt of U4 reflectors in the eastern part of the margin suggests changes in continental slope gradient and the predominant role of tectonic movements rather than eustatic effects or sediment supply. In this way, we can highlight an uplift phase leading to the deposition of debris flows in U5 at the foot of the slope as well as erosion on the slope (Fig. 8). The occurrence of debris flows in U4 appears before the tilting of U4 reflectors, so it is therefore independent of the uplift event.

We can recognize major differences between the eastern and western parts of the Dhofar margin (Fig. 4). These differences concern the sedimentation pattern, canyon morphologies (large or linear), the gradient of the continental slope and the substratum configuration, and could be the result of two distinct deformational regimes. In the western part, the differential vertical movement is restricted to a narrow zone characterized by a major fault (Fig. 4A). Seaward of this fault, the slope is gentle and characterized by linear canyons and the preservation of units U4 and U5. In the eastern part, the differential vertical motion takes place over the entire slope and leads to an increase in gradient (Fig. 4B). During the uplift phase, the erosional power of canyons increases and the sedimentary depocentre is shifted toward the basin (Fig. 8).

To summarize, the post-rift history of the Dhofar margin can be characterized firstly by the sudden occurrence of debris flows over the entire margin and secondly by an uplift affecting differently the eastern and western parts of the margin. The boundary between U3 and U4 (i.e. the earliest occurrence of debris flows) extends in the basin above oceanic crust younger than $10 \mathrm{Ma}$ (magnetic anomaly 5). Thus, we conclude that the earliest occurrence of debris flows and the subsequent major uplift affected the Dhofar margin after 10 Ma ago, that is, at least 7.6 Ma after the end of rifting.

\section{Discussion}

The types of parameter contributing to the initiation of MTCs can be categorized either as "triggers" (earthquakes, storm-wave loading, tilting due to margin subsidence, salt diapirism, changes in methane hydrate stability and sea-level changes) or "preconditioning" factors (sediment properties: water content and pore pressure). The MTCs of the Brazos-Trinity slope system (Texas continental slope) were classified by Beaubouef and Abreu (2010) into two different types, namely intra-basinal and extrabasinal. Intra-basinal MTCs are derived from within the basins as slumps or slides from over-steepened 
areas of the collapsed basin margin. They occur in response to local processes unique to each basin, and may occur at any time during the basin evolution regardless of sea-level stage. Extra-basinal MTCs are derived from areas outside and up-dip of the basins, entering the basin via various feeder channels (Beaubouef and Friedman, 2000). They tend to be more laterally extensive and have point sources, exhibiting fan-like patterns in plan. Extra-basinal MTCs may occur in response to allocyclic processes, and, therefore, may have some significance in terms of sequence stratigraphic. On the Dhofar margin, any comparison with known local or global events must be considered hypothetical owing to the approximate nature of dating of the MTCs. Some lines of evidence can nevertheless be mentioned.

From offshore observations, we identify a post-rift uplift phase (post chron 5, $10 \mathrm{Ma}$ ) on the Dhofar margin. Comparable observations have been made based on field studies (Platel and Roger, 1989). The major uplift phase (rift shoulder uplift) is attributed to the end of the Burdigalian, well before $10 \mathrm{Ma}$. However, southern Dhofar underwent a final major uplift from Middle Miocene to Pliocene times, creating the impressive cliffs that rim the Salalah plain, with rejuvenation of the major listric faults (Platel and Roger, 1989). This is highlighted by the basal conglomerates interstratified with carbonates, which are overlain by thick piedmont deposits north of the Dhofar mountains (Roger, et al., 1989, Platel, et al., 1992). The evidence for this uplift is supplemented by Pleistocene beach-rocks located a few metres above present sea-level in the Salalah region (Platel and Roger, 1989).

Three hypotheses can account for the late-stage uplift of the Dhofar margin. The first hypothesis invokes the channelling of mantle plume flow coming from the Afar hot spot as well as small-scale convection triggering recent volcanic activity in Somalia, Yemen up to Longitude $54^{\circ} \mathrm{E}$ (Leroy, et al., 2010). This hypothesis would explain i) the presence of a volcano in the western deep margin of the study area (Lucazeau, et al., 2009, Autin, et al., 2010); ii) off-axis volcanic activity in the adjoining oceanic segment (d'Acremont, et al., 2010) and iii) zones of partial melting in the mantle below the northern part of our study area (Basuyau, et al., 2010). The second hypothesis involves intraplate compressional deformation, which is a common feature in the post-rift evolution of many passive margins and rifts (Cloetingh, et al., 2008). The convergence between the Arabian and Eurasian plates to the NE may cause this type of deformation. A third hypothesis considers the flexural effects of erosional unloading due to contrasts in denudation rate (Gilchrist and Summerfield, 1990, Ten Brink and Stern, 1992). Molnar and England (1990) point out that increases in erosion rate (due, for example, to climate change) could lead to an increased uplift. According to this hypothesis, global sea-level changes and climatic conditions during the Pleistocene, which appear associated with many of the MTCs studied worldwide (Maslin, et al., 2004), could have influenced the uplift phase. On the contrary, according to Gilchrist et al. (1994), isostatic uplift due to river valley incision would be only of limited importance (in relation to the tectonic effects).

Even if uplift affected the more recent triggering of debris flows, it does not explain the earlier occurrence (in U4). The deposition of the U4 debris flows over a wide area of the Dhofar margin could be the result of numerous different mechanisms. Among these mechanisms, we could propose a pronounced sea-level fall ( $\sim 100 \mathrm{~m})$ at the Serravallian/Tortonian boundary (TB3.1 cycle (Haq, et al., 1987)), the onset of the monsoon system in the western Arabian Sea around the middle Miocene (Prell and shipboard party of ODP Leg 117, 1990), or its intensification around 7-8 Ma (Kroon, et al., 1991, Prell and Kutzbach, 1992). However, we require accurate dating of U4 and U5 before better constraints on these events can be obtained from our observations

\section{Conclusion}

The study of the sedimentation pattern on the Dhofar margin highlights two major events in the last $10 \mathrm{Ma}$ of its formation. The first event is characterized by a major change in the sedimentation pattern. Indeed, the sudden deposition of debris flows at the foot of the present-day slope contrasts with the previous well lithified post-rift sedimentary units. The second event is characterized by an uplift that considerably accentuates the gradient of the eastern part of the margin, leading to slope instabilities and an increased abundance of debris flow deposits. 
The observed topography of the Dhofar margin has been attributed to the combined effect of climate, sedimentary loading and flexural rigidity (Petit, et al., 2007). The present study shows that other mechanisms may have a role. Indeed, post-rift deformation, involving tectonic reactivation, has strongly affected the structure and infilling of numerous extensional basins and passive margins, which explains why their early history can be difficult to decipher. Such a phenomenon has been illustrated, for example, in the Black Sea and the Pannonian Basin systems (Cloetingh, et al., 2008). The recognition of post-rift deformational events on the Dhofar margin offers new perspectives for the unravelling of its early history.

\section{Acknowledgements}

This study was funded by CNRS-INSU, Actions Marges - Aden, ANR YOCMAL and CNRSPICS Oman. We are grateful to Drs Hilal Al-Azri and Salim Al Busaidi, as well as the Oil and Gas Ministry of Oman. We acknowledge the editor of Terra Nova , *****, and journal reviewers for their advice and comments on the manuscript. M.S.N. Carpenter post-edited the English style.

\section{References}

Amante, C. and Eakins, B.W., 2009. ETOPO1 1 Arc-Minute Global Relief Model: Procedures, Data Sources and Analysis. NOAA Technical Memorandum NESDIS NGDC-24.

Autin, J., Leroy, S., Beslier, M.O., d'Acremont, E., Razin, P., Ribodetti, A., Bellahsen, N., Robin, C. and Al-Toubi, K., 2010. Continental break-up history of a deep magma-poor margin from seismic reflection data (northeastern Gulf of Aden margin, offshore Oman). Geophys. J. Int., 180, 501519.

Basuyau, C., Tiberi, C., Leroy, S., Stuart, G., Al-Lazki, A., Al-Toubi, K. and Ebinger, C., 2010. Evidence of partial melting beneath a continental margin: case of Dhofar, in the Northern Gulf of Aden (Sultanante of Oman). Geophys. J. Int., 180, 520-534.

Beaubouef, R.T. and Abreu, V., 2010. MTCs of the Brazos-Trinity Slope System; Thoughts on the Sequence Stratigraphy of MTCs and Their Possible Roles in Shaping Hydrocarbon Traps. In: Submarine Mass Movements and Their Consequences. (D.C. Mosher, R. Craig Shipp, L. Moscardelli, J.D. Chaytor, C.D.P. Baxter, H.J. Lee and R. Urgeles, eds). Springer Netherland, pp. 475-490.

Beaubouef, R.T. and Friedman, S.J., 2000. High resolution seismic/sequence stratigraphic framework for the evolution of Pleistocene intra slope basins, Western Gulf of Mexico: depositional models and reservoir analogs. In: Deep-Water Reservoirs of the World. (P. Weimer, R.M. Slatt, J. Coleman, N.C. Rosen, H. Nelson, A.H. Bouma, M.J. Styzen and D.T. Lawrence, eds). GCSSEPM Foundation, 20th Annual Bob F. Perkins Research Conference, Houston.

Borgomano, J.R.F. and Peters, J.M., 2004. Outcrop and seismic expressions of coral reefs, carbonate platforms, and adjacent deposits in the tertiary of the Salalah Basin, South Oman. In: Seismic imaging of carbonates reservoirs and systems. AAPG Memoir 81, pp. 251-266.

Bott, W.F., Smith, B.A., Oakes, G., Sikander, A.H. and Ibrahim, A.I., 1992. The tectonic framework and regional hydrocarbon, prospectivity of the Gulf of Aden. J. Petrol. Geol., 15, 211-243.

Brami, T.R., Pirmez, C., Archie, C. and Holman, K., 2000. Late Pleistocene deep-water stratigraphy and depositional processes, offshore Trinidad and Tobago. In: Deep-Water Reservoirs of the World. (P. Weimer, R.M. Slatt, J. Coleman, N.C. Rosen, H. Nelson, A.H. Bouma, M.J. Styzen and D.T. Lawrence, eds). GCSSEPM Foundation, 20th Annual Bob F. Perkins Research Conference, Houston.

Cloetingh, S., Beekman, F., Ziegler, P.A., Van Wees, J.D. and Sokoutis, D., 2008. Post-rift compressional reactivation potential of passive margins and extensional basins. Geological Society, London, Special Publications, 306, 27-70. 
d'Acremont, E., Leroy, S., Beslier, M.O., Bellahsen, N., Fournier, M., Robin, C., Maia, M. and Gente, P., 2005. Structure and evolution of the eastern Gulf of Aden conjugate margins from seismic reflection data. Geophys. J. Int., 160, 869-890.

d'Acremont, E., Leroy, S., Maia, M., Gente, P. and Autin, J., 2010. Volcanism, jump and propagation on the Sheba Ridge, eastern Gulf of Aden: segmentation evolution and implications for accretion processes. Geophys. J. Int., 180, 535-551.

d'Acremont, E., Leroy, S., Maia, M., Patriat, P., Beslier, M.O., Bellahsen, N., Fournier, M. and Gente, P., 2006. Structure and evolution of the eastern Gulf of Aden: insights from magnetic and gravity data (Encens-Sheba/MD117 cruise). Geophys. J. Int., 165, 786-803.

Farr, T.G., Rosen, P.A., Caro, E., Crippen, R., Duren, R., Hensley, S., Kobrick, M., Paller, M., Rodriguez, E., Roth, L., Seal, D., Shaffer, S., Shimada, J., Umland, J., Werner, M., Oskin, M., Burbank, D. and Alsdorf, D., 2007. The Shuttle Radar Topography Mission. Rev. Geophys., 45.

Fournier, M., Patriat, P. and Leroy, S., 2001. Reappraisal of the Arabia-India-Somalia triple junction kinematics. Earth Planet. Sci. Lett., 189, 103-114.

Gilchrist, A.R., Kooi, H. and Beaumont, C., 1994. Post-Gondwana geomorphic evolution of southwestern Africa: Implications for the controls on lanscape development from observations and numerical experiments. Journal of geophysical research, 99.

Gilchrist, A.R. and Summerfield, M.A., 1990. Differential denudation and flexural isostasy in formation of rifted-margin upwarps. Nature, 346, 739-742.

Haq, B.U., Hardenbol, J. and Vail, P., 1987. Chronology of fluctuating sea levels since the Triassic (250 million years ago to present). Science, $\mathbf{2 3 5}, 1156-1167$.

Jestin, F., Huchon, P. and Gaulier, J.M., 1994. The Somalia plate and the East African Rift System: present kinematics. Geophys. J. Int., 116, 637- 654.

Kroon, D., Steens, T. and Troelstra, S.R., 1991. Onset of monsoonal related upwelling in the western Arabian Sea as revealed by planktonic foraminifers. In: Proc. ODP, Sci. Results (W.L. Prell, N. Niitsuma and al., eds), College Station, TX (Ocean Drilling Program), pp. 257-261.

Leroy, S., d'Acremont, E., Tiberi, C., Basuyau, C., Autin, J., Lucazeau, F. and Sloan, H., 2010. Recent off-axis volcanism in the eastern Gulf of Aden: implications for plume-ridge interaction. Earth Planet. Sci. Lett., 293, 140-153.

Leroy, S., Ebinger, C., d'Acremont, E., Stuart, G., Al-Lazki, A., Tiberi, C., Autin, J., Watremez, L., Beslier, M.O., Bellahsen, N., Lucazeau, F., Perrot, J., Mouthereau, F., Courrèges, E., Huchon, P., Rouzo, S., Bahalaf, S., Sholan, J., Unternehr, P., Hello, Y., Anglade, A., Desprez, O., Beguery, L., Aouji, O., Daniel, R., Al-Toubi, K., Sage, F. and Khanbari, K., 2006. The onshore-offshore ENCENS project: Imaging the stretching/thinning of the continental lithosphere and inception of oceanic spreading in the eastern Gulf of Aden. In: AGU Fall meeting. AGU, San Francisco.

Leroy, S., Gente, P., Fournier, M., d'Acremont, E., Patriat, P., Beslier, M.O., Bellahsen, N., Maia, M., Blais, A., Perrot, J., Al-Kathiri, A., Merkouriev, S., Fleury, J.M., Ruellan, P.Y., Lepvrier, C. and Huchon, P., 2004. From rifting to spreading in the eastern Gulf of Aden: a geophysical survey of a young oceanic basin from margin to margin. Terra Nova, 16, 185-192.

Leroy, S., Lucazeau, F., d'Acremont, E., Watremez, L., Autin, J., Rouzo, S., Bellahsen, N., Tiberi, C., Ebinger, C., Beslier, M.O., perrot, J., Razin, P., Rolandone, F., Stuart, G., Al Lazki, A., Al-Toubi, K., Bache, F., Bonneville, A., Goutorbe, B., Huchon, P., Unternehr, P. and Khanbari, K., in revision. Contrasted styles of rifting in the eastern Gulf of Aden: a combined wide-angle MCS and Heat flow survey. G-Cubed.

Lucazeau, F., Leroy, S., Autin, J., Bonneville, A., Goutorbe, B., Watremez, L., d'Acremont, E., Düsünur, D., Rolandone, F., Huchon, P., Bellahsen, N. and Tuchais, P., 2009. Post-Rift volcanism and high heat-flow at the Ocean-Continent Transition of the Gulf of Aden. Terra Nova, 21, 285-292.

Lucazeau, F., Leroy, S., Bonneville, A., Goutorbe, B., Rolandone, F., d'Acremont, E., Watremez, L., Düsünur, D., Tuchais, P., Huchon, P., Bellahsen, N. and Al-Toubi, K., 2008. Persistent thermal activity at the Eastern Gulf of Aden after continental break-up. Nature Geoscience, 1, 854-858. 
Manley, P.L. and Flood, R.D., 1988. Cyclic deposition within Amazon deep-sea fan. Am. Assoc. Pet. Geol. Bull., 72, 912-925.

Martinez, J.F., Cartwright, J. and Hall, B., 2005. 3D seismic interpetation of slump complexes: examples from the continental margin of Israel. Basin Res., 17, 83-108.

Maslin, M., Owen, M., Day, S. and Long, D., 2004. Linking continental slope-failures and climate change: Testing the Clathrate gun hypothesis. Geology, 32, 53-56.

Masson, D.G., van Niel, B. and Weaver, P.E., 1997. Flow processes and sediment deformation in the Canary debris flow on the NW African continental rise. Sediment. Geol., 110, 163-179.

Molnar, P. and England, P., 1990. Late Cenozoic uplift of mountain ranges and global climate change: chicken or egg? Nature, 346, 29-34.

Moscardelli, L., Wood, L. and Mann, P., 2006. Mass-transport complexes and associated processes on the offshore area of Trinidad and Venezuela. Am. Assoc. Pet. Geol. Bull., 90, 1059-1088.

Petit, C., Fournier , M. and Gunnell, Y., 2007. Tectonic and climatic controls on rift escarpments: Erosion and flexural rebound of the Dhofar passive margin (Gulf of Aden, Oman). Journal of Geophysical Research, 112.

Platel, J.P. and Roger, J., 1989. Evolution géodynamique du Dhofar (Sultanat d'Oman) pendant le Crétacé et le Tertiaire en relation avec l'ouverture du golfe d'Aden. Bull. Soc. Géol. Fr., 2, 253-263.

Platel, J.P., Roger, J., Peters, T., Mercolli, I., Kramers, J.D. and Le Métour, J., 1992. Geological Map of Salalah (1/250 000), Sultanate of Oman; sheet NE 40-09. Ministry of Petroleum and Minerals, Directorate General of Minerals, Oman.

Posamentier, H.W. and Kolla, V., 2003. Seismic geomorphology and stratigraphy of depositional elements in deep water settings. J. Sediment. Res., 73, 367-388.

Prell, W.L. and Kutzbach, J.E., 1992. Sensitivity of the Indian monsoon to forcing parameters and implications for its evolution. Nature, 360, 647-651.

Prell, W.L. and shipboard party of ODP Leg 117, 1990. Neogene tectonics and sedimentation of the SE Oman continental margin: results from ODP Leg 117. In: The Geology and Tectonics of the Oman Region. (A.H.F. Robertson, M.P. Searle and A.C. Ries, eds). Geological Society Special Publication $\mathrm{N}^{\circ}$ 49, London, pp. 745-758.

Roger, J., Platel, J.P., Cavelier, C. and Bourdillon-de-Grisac, C., 1989. Données nouvelles sur la stratigraphie et l'histoire géologique du Dhofar (Sultanat d'Oman). Bull. Soc. Géol. Fr., 2, 265277.

Ten Brink, U.S. and Stern, T., 1992. Rift flank uplifts and hinterland basins: comparison of the Transantartic Mountains with the Great Escarpment of Southern Africa. J. Geophys. Res., 97, 569585.

Vail, P.R., Mitchum, R.M., Todd, R.G., Widmier, J.M., Thompson, S., Sangree, J.B., Bubb, J.N. and Hatlelid, W.G., 1977. Seismic stratigraphy and global changes of sea-level. American Association of Petroleum Geologists, Tulsa. 


\section{Figure captions}

Figure 1. A. General setting of the study region. White arrows indicate relative plate motions between the Arabian and African plates. Topography and bathymetry after ETOPO1 Global Relief Model (Amante and Eakins, 2009). AFFZ: Alula Fartak fracture zone. SHFZ: Socotra Hadbeen fracture zone. B. Database used for this study. Two seismic datasets derived from oil industry sources (in black and blue), and two seismic datasets acquired during the ENCENS-SHEBA (Leroy, et al., 2004) and ENCENS (Leroy, et al., 2006, Leroy, et al., in revision) cruises (in green and red, respectively). Topography after the global SRTM model (Farr, et al., 2007) and bathymetry from multibeam data acquired during the ENCENS-SHEBA cruise.

Figure 2. Topographic map (Farr, et al., 2007) and bathymetry (Leroy, et al., 2004, Lucazeau, et al., 2008, Leroy, et al., in revision) of the Dhofar margin showing clear examples of scarps (1), slumps (2), large canyons (3), linear canyons (4) and channels (5). The upper and lower limits of the slope are outlined. The dashed line representing isochron 5d (17.6 Ma) is based on Leroy et al. (in revision). AFFZ: Alula Fartak Fracture Zone. SHFZ: Socotra Hadbeen Fracture Zone.

Figure 3. Isopach map (in seconds TWTT) of syn-rift (U1) and post-rift (U2 to U5) sediments. Major faults affecting the substratum are indicated. The dashed line representing isochron $5 \mathrm{~d}(17.6 \mathrm{Ma})$ is based on Leroy et al. (in revision). AFFZ: Alula Fartak Fracture Zone. SHFZ: Socotra Hadbeen Fracture Zone.

Figure 4. Line drawings perpendicular to the Dhofar margin (location on Fig. 2). Pre-rift substratum, Ocean-Continent transition and Oceanic crust are represented in grey. Syn-rift (U1) to postrift (U2-U3) units are represented in white. Late post-rift units (U4-U5) are colour coded.

Figure 5. Encens 47 seismic profile crossing the DIM graben at the toe of the slope (location on Fig. 2). Above the acoustic basement, units U2-U3 are characterized by high-amplitude, parallel and highly continuous reflection configurations. Two debris flow events can be observed, occurring within units U4 and U5.

Figure 6. Seismic profile 880813 located on the eastern slope of the Dhofar margin (location on Fig. 2). U4 is characterized by channels. U5 is not observed on this part of the continental slope.

Figure 7. Seismic profile 880812 located on the eastern slope of the Dhofar margin (location on Fig. 2). U4 is deeply incised by a large canyon.

Figure 8. Palaeogeographic evolution of the Dhofar margin between deposition of U4 and U5. (A) first sudden onset of debris flows in the DIM graben during deposition of U4. (B) uplift movement, mainly occurring on the eastern part of the margin, following the first depositional event. 


\section{Figures}

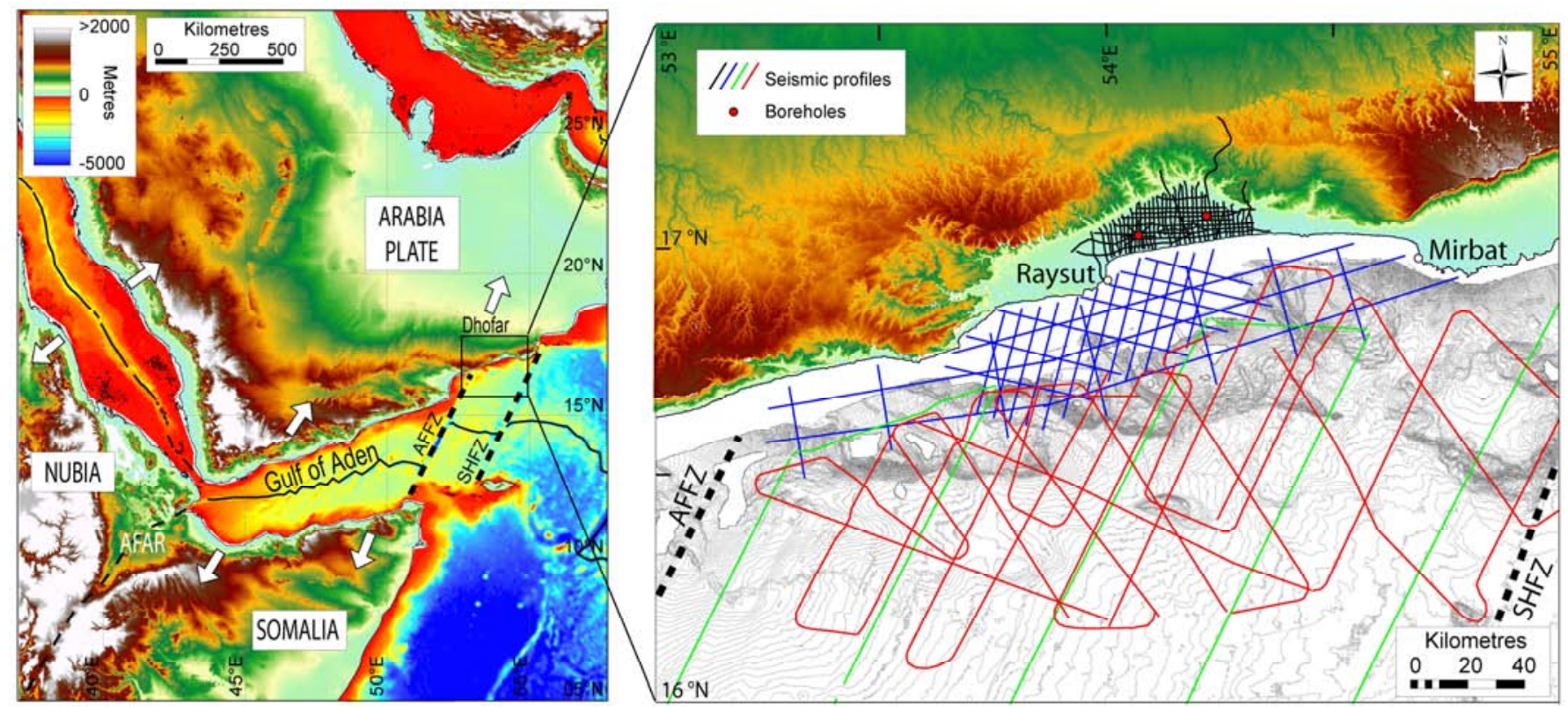

Figure 1.

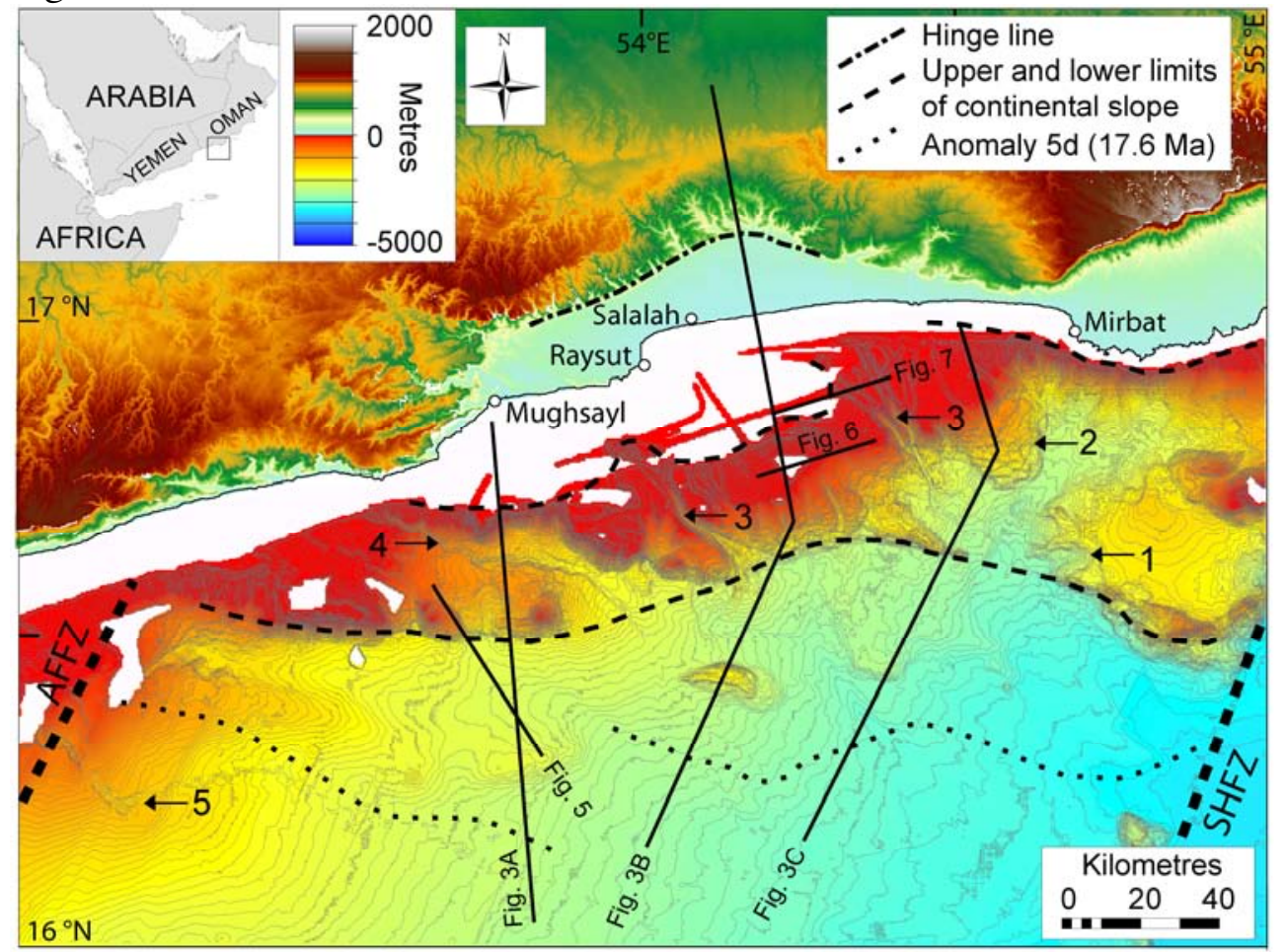

Figure 2. 


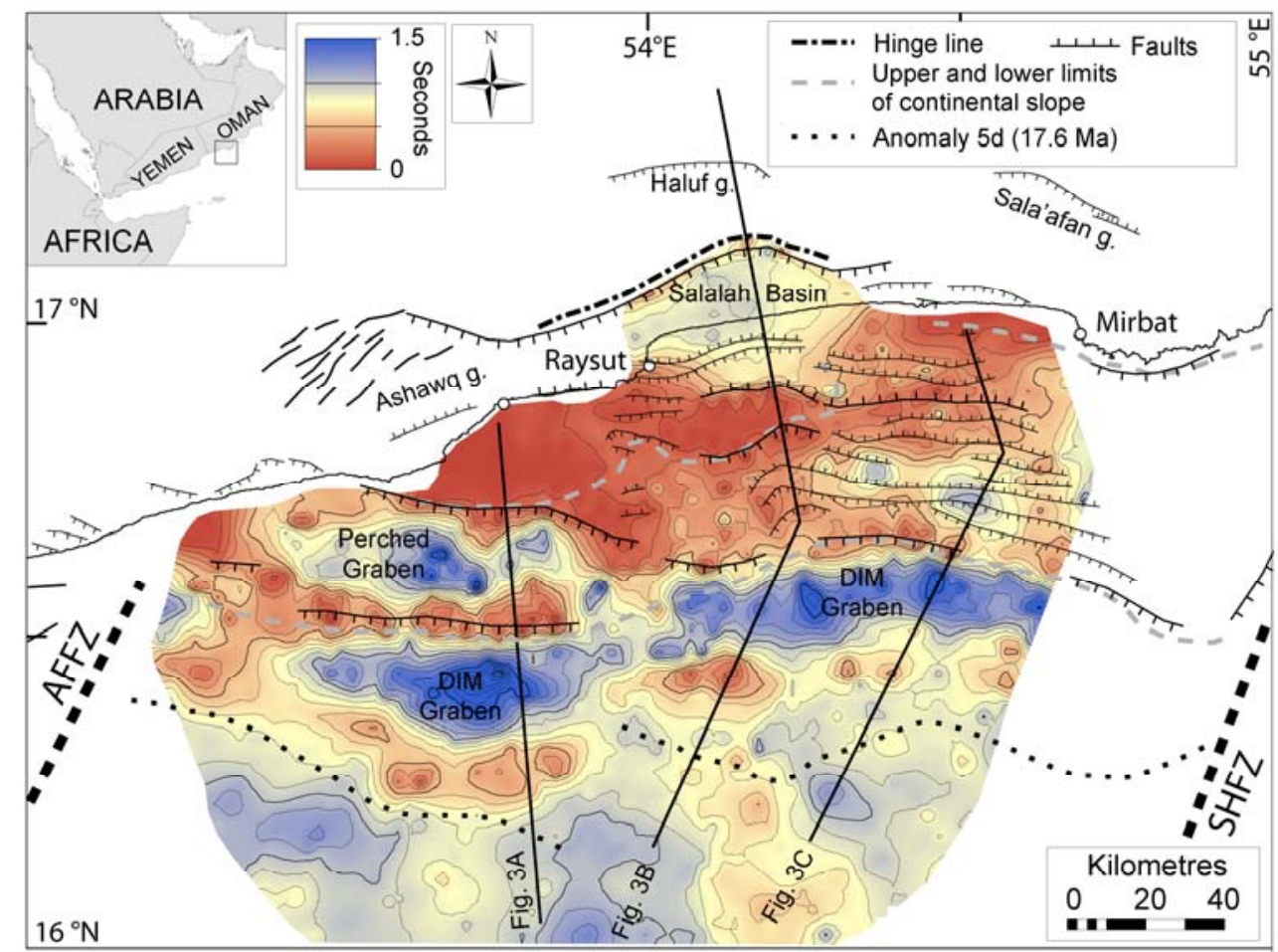

Figure 3.

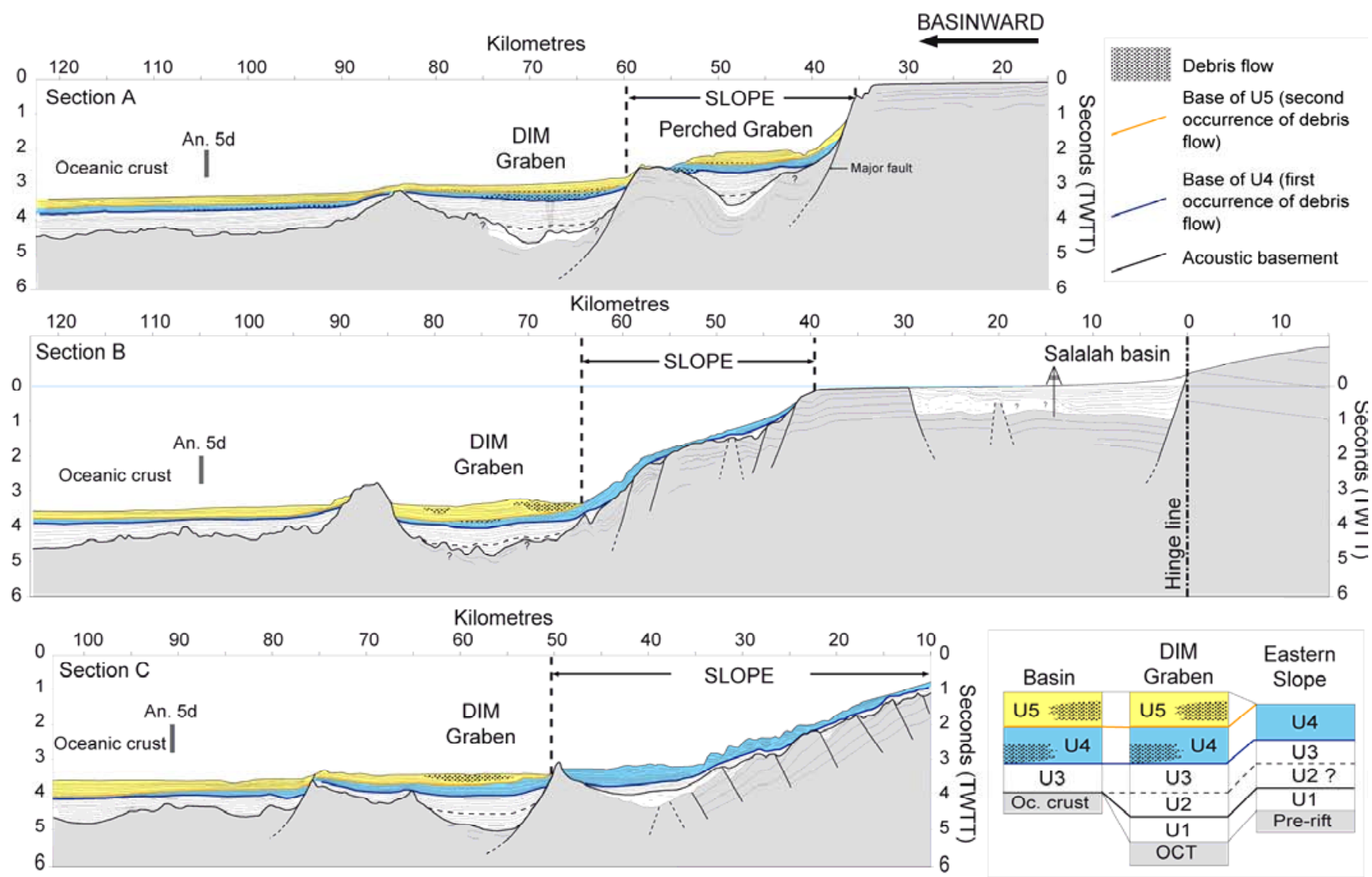

Figure 4. 


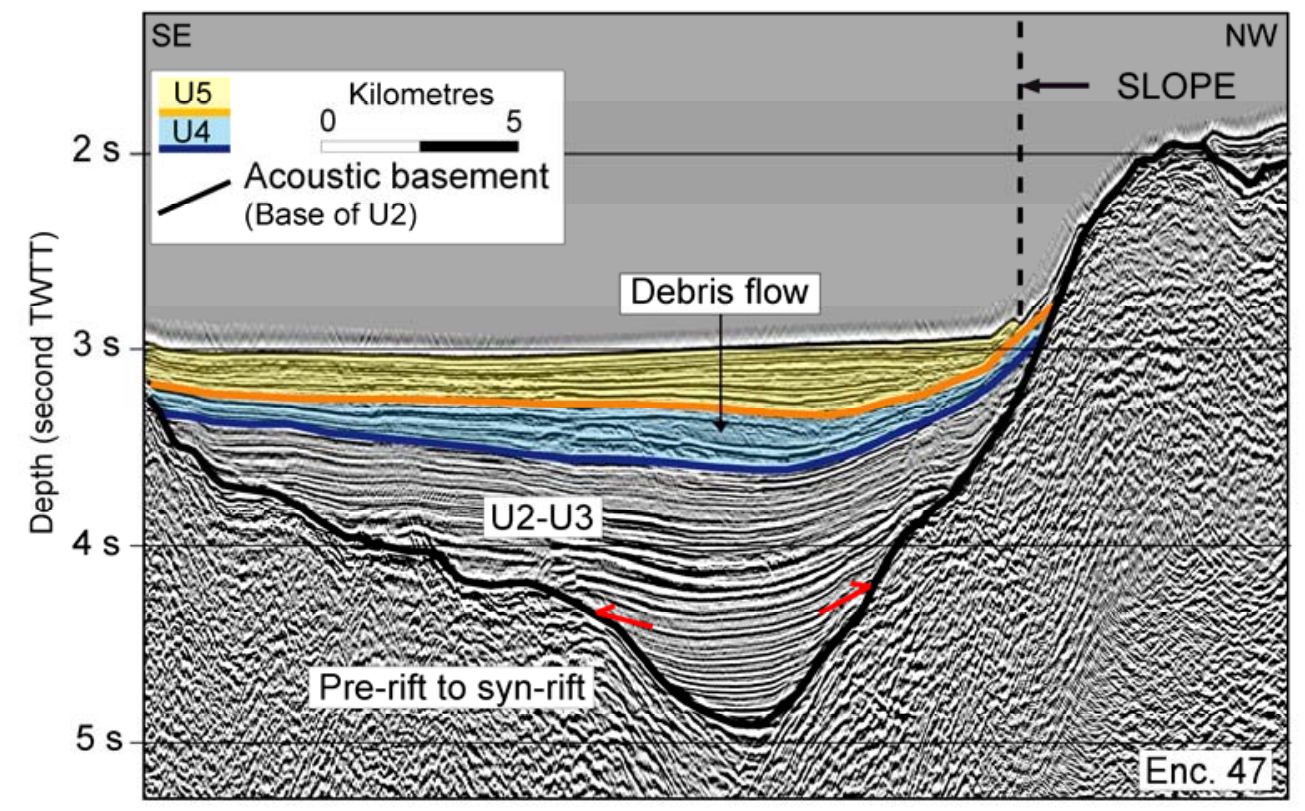

Figure 5.

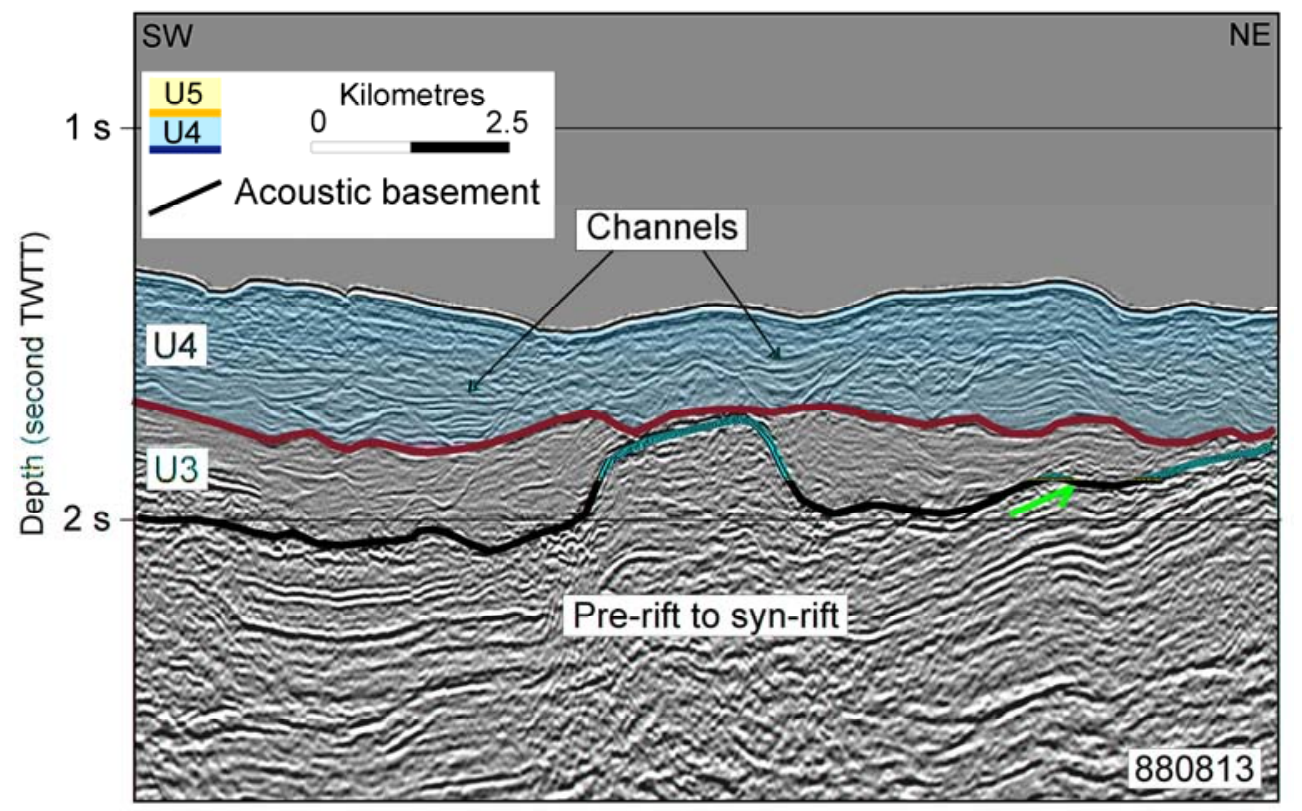

Figure 6. 


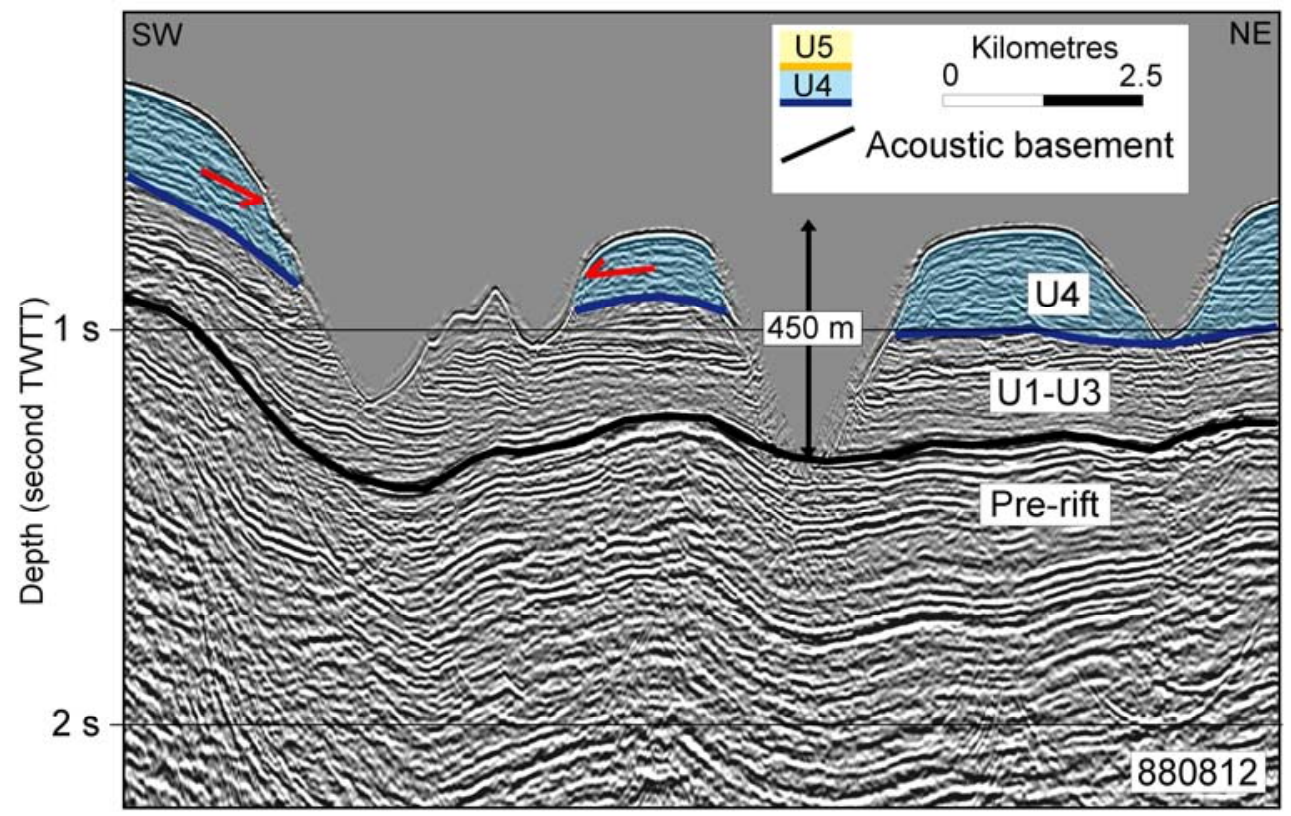

Figure 7.
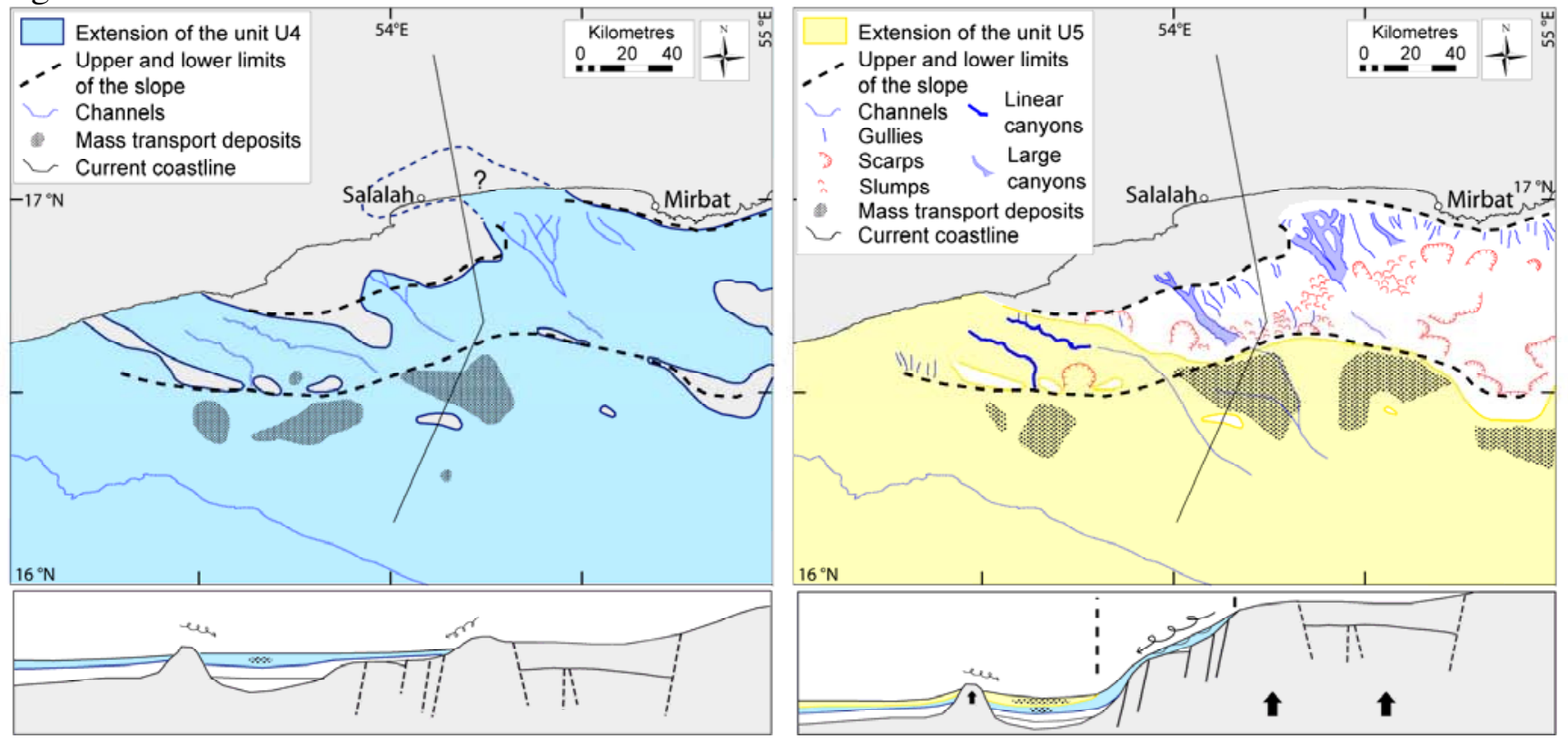

Figure 8. 